\title{
Social Capital as a Source of Business Advantages for a Woman Entrepreneur in the Context of Small-Size Business
}

\author{
Won-jun Lee ${ }^{1}$ \\ ${ }^{1}$ Department of Business Administration, Cheongju University, Korea \\ Correspondence: Won-jun, Lee, Department of Business Administration, Cheongju University, Korea. Tel: \\ 82-10-6741-5423. E-mail: marketing@ cju.ac.kr
}

Received: November 25, 2014

Accepted: December 10, 2014 Online Published: April 30, 2015

doi:10.5539/ass.v11n12p155

URL: http://dx.doi.org/10.5539/ass.v11n12p155

\begin{abstract}
Social capital can be defined as the totality of resources by virtue of possessing social ties. Grounded along the previous research, this research examines the relation between the social capital of woman entrepreneurs and their small companies' market performance mediated by competitive advantages. A survey of 257 entrepreneurs who is woman in Korea found that structural social capital and cognitive, social capital positively influence both differentiation advantage and cost advantage. The empirical results also indicate that those advantages affect market performance significantly. However, the impacts of relational social capital are not significant.

The main theoretical contribution of this study is that it confirms the importance of social capital for woman entrepreneurs. It also supports the relevance of social capital in producing competitive advantages which lead to a better market performance. This study provides woman entrepreneurs in SMBs with managerial implications. The result shows that woman entrepreneurs can create business advantage by creating social ties and promoting social capital.
\end{abstract}

Keywords: social capital, competitive advantage, market performance, woman entrepreneurs, SMB

\section{Introduction}

Creating own business has become a popular business trend in Korea. Since the 2000s, economic policies in Korea have refocused their attention from depending on the 'Chabol' to supporting SMEs in order to fortify the source of the national economy's competitive strength and to develop dynamic and creative economy. During the transition, women's role has been noteworthy and the number of woman entrepreneurs has increased.

Women who are vigorously pushing forward small business are a worldwide phenomenon. The pace of new business formation by women has out-paced the rate by men in the most countries already (Minniti \& Naude 2010), and the issue of female entrepreneurship continues to draw substantial interest from the government, researcher and academics (Chung et al., 2012).

Nevertheless, today's woman entrepreneurs are facing many troubles in spite of their quantitative growth. They tend to small, weak and are not competitive yet. For example, more than $93 \%$ of woman entrepreneurs own small-scale enterprises that hire less than five people in Korea (Lee et al., 2011). The number of failed woman entrepreneurs is also rising quickly.

Thus, interpreting the success factors of woman entrepreneurs becomes a critical academic and managerial issue. The purpose of this study is to investigate the relationships between social capital and market performance to understand woman entrepreneurs working in small business. Understanding the meaning and value of social capital has become a considerably important research issue in social science given social capital's influence on a firm's ability to enhance the marketing capability (Adler \& Kwon, 2002), and we believe that the social capital would be more important for woman entrepreneurs than for men counterparts. Some studies viewed gender difference as a key variable that influences entrepreneurship activities. These previous research results found men entrepreneurs have much stronger intentions to start their own business than women counterparts have (Sandra et al., 2006). However, some scholars argued that individual level variables such as gender were insufficient to explain who became an entrepreneur (Chung et al., 2012). A new research topic such as social capital can be a key to understand gender difference when the previous research results fail to reach an accord. . 
The rest of this research progresses in the following order: a brief theoretical background of female entrepreneurship and social capital; a review of related literature, which leads to our research model conceptualization; an overview of research methodology and hypothesis of the current study; presentation of research findings, implications, and further research directions.

\section{Theoretical Background}

\subsection{Rapid Progress of Woman Entrepreneurs}

An entrepreneur is often defined as "someone who starts his own small business" (MacMillan Dictionary of Modern Economy, 1999, p. 216), and entrepreneurs are the most important players in the economy. They are creators of new wealth, new jobs and inventors of new products and service (Padma, 2013). As a result, it is very natural that more interests are paid to entrepreneurs and new business creation and recently woman entrepreneurs' activity to create new business is increasing.

Woman entrepreneurship is a new emerging economic force today. The period of 1975-1990 witnessed a dramatic increase in the number of women who entered self-employment. It was only $25 \%$ of self-employed workers in 1975 but the number grew to $30 \%$ by 1990 (Budig, 2006). Also the number of women-owned business increased by 42 percent between 1997 and 2006 (Padma, 2013). The welfare resulting from female entrepreneurship is higher than that resulting from the activity of men (Minniti, 2010). Woman entrepreneurs' presence as policy makers and expanding capacity to serve the global business cannot be ignored.

There are explanations for women who women leave the corporate to do new business creation. Fielden et al. (2003) identified a number of the key reasons in determining their decision to leave. According to their research, in general, women workers are not being taken seriously and they consistently encounter a glass ceiling in their promotion and poorer pay. As a result, they see men promoted ahead of them and feel isolated in their corporation. To solve the problem, some of the women workers become entrepreneurs and start their own business. On the motivation study to explain women's new business creation, Mackay (2001) identifies the main reasons for women to become entrepreneurs as independence, autonomy, job loss and more flexibility giving women more opportunities to spend time together with their family members.

However, the importance of woman entrepreneurs in Korea had not been emphasized before the 1990s. Traditionally, Korean women have existed within the Confucious framework of 'Hyunmo Yangcheo' ideology which means 'loving wife and good mother' in Korean. As a result, Korean women are expected to stay inside their homes traditionally. These low expectations about the societal role of women have kept them in traditional role regardless of rapid social changes and women's capability to do business. According to Mackie (2003), these traditional roles in Asia nations are changing now. From 1970s to 1990s, Japanese feminist groups worked to reform the practice and Korean women also worked in their ways.

Compared to other Asian women, Korean women have a better position in creating new business. Female entrepreneurs in Korea are usually innovation driven and better educated comparing to other Asian nations (Padma, 2013). In 2001, Korea was ranked to be the higher group of necessity entrepreneurship in Asia and recently, the Korean government and domestic policies show increased attention to encouraging female entrepreneurship. None the less gender discrimination in the business world remains in Korea society, the Korean government and companies support reform to stimulate more woman entrepreneurs.

However, resistance remains for changing the country's male-dominated business culture and customs. Related entrepreneurship research is a man-oriented activity and woman is stll out of concern. Only a limited number of entrepreneurship studies focused on female-owned business (Berg, 1997). Also, As a result, most entrepreneurship theories that have been developed can be named as theories of male entrepreneurship since they are based on studies that excluded women (Budig, 2006).

\subsection{Characteristics of Woman Entrepreneurs}

There has been relatively little research on woman entrepreneurs. One of the reasons for the scarcity of related research is that people believe there is not any actual differences between men and woman entrepreneurs' activities to be a successful one (Gartner, 2001). However, thanks to an increase in the availability of data and to an improvement in the related research, a significant amount of facts on female entrepreneurs are revealed.

Minniti and Naude (2010) insisted that research on female entrepreneurship has expanded to a variety of disciplines. In the 1970s and 1980s, most of these studies tried to identify the role of gender and focused on who the women entrepreneur was compared to men entrepreneur. In the 1990s, these studies were inspired by feminism and paid more attention to the prominent role of women entrepreneur. At the same time, other studies tried to link female entrepreneurship to the allocation of family resources, marriage and childbearing decision, 
self-confidence and poverty in an alternative to the feminist approach (Snyder, 1995; Blau \& Kahn, 2007). In the 2000 s, research has been conducted on issues related to professional characteristics, motherhood, family position, human capital, and social entrepreneurship (Steward et al., 2003; William, 2004).

The majority of early study tended to find more similarities than differences between men and woman entrepreneurs. According to these studies, both men and woman entrepreneurs often cited reasons such as avoiding low pay, escaping supervision, seeking independence and opportunity as factors driving their motivations to be an entrepreneur (Birley, 1989; Hisrich et al., 1996; Fielden et al., 2003).

However, gender difference becomes a major research topic again. In her book 'Understanding the Gender Gap', Goldin (1990) legitimized the study of women's labor behavior and inspired a significant amount of research on female entrepreneurship. Since then many researchers have studied the gender differences in entrepreneurship. Researchers suggest that there is no direct link between formal education and business success (Stanger et al., 2002). However, gender difference is likely to exist. For instance, man and woman entrepreneurs are different in family responsibilities. Women are more likely than men to shoulder family responsibilities and this leads to women having to combine their work duties and home responsibilities, limiting the scope of business (Low, 2008; Dhaliwal et al., 2009). Research results indicate that the probability of self-employment is higher for men. According to Minniti and Levesque (2008), early-stage entrepreneurial activity participation for men are 50 percent higher than those of women in most countries. The existence of a ratio of early-stage female to male entrepreneurship suggests that entrepreneurial attitudes are influenced by gender factor. It is also known that women's business tends to be smaller and to grow less than those owned by men (Coleman, 2007).

Women and men have different socioeconomic characteristics such as education, wealth, social status. Female entrepreneurs tend to possess fewer years of job experience than men (Lee \& Rendall, 2001). Female and male entrepreneurs also differ to their personal and business profile. They are different in business sectors, products and service, management goals and business structure (Verhies, 2003).

The gender difference in terms of earning is more clear in the SME sector. It is known that female entrepreneurs has less work experience compare to the male entrepreneurs and self-employed women earn less than self-employed men (Devine, 1994, Parker, 2009). Profitability also worse than men's business and their business generate lower sales turnover than men, even in same industry comparison (Buttner, 1993; Chaganti \& Parasuraman, 1996).

\subsection{Social Capital and Business Success}

Recently, some researchers insist that one of the biggest differences between man and woman can be found in the area regard to their networking strategy (Shim \& Eastlick, 1998). According to their research, female entrepreneurs' social network differs from the male counterparts' network. Aldrich (1989) found that male entrepreneurs' social network rarely encompass females while female entrepreneurs' social networks encompass more male.

To explain these differences of networking activities between gender, this study tries to use the social capital concept which is relatively new in marketing studies. The concept of social capital has a long history in the social studies. The proposition of social capital theory insists that social relationships are valuable because they make their members to acquire necessary resources from one another through social networks. In the oriental countries social ties have been a very important factor for business success. For instance, 'Quanxi' is a very popular way to do business in China (Peng \& Luo, 2000). The development of social capital with key business accounts in the Chinese market is not an option but a must and Korea market is not an exception. As a result, social capital, which is a joint concern for all social science today is used across multiple disciplines (Batt, 2008). Yet marketing researchers have been slow in investigating the implications of social capital in business practice.

The social capital study focuses on accessing intangible resources such as goodwill from the social network and emphasizes the networks and relationships as a critical component. According to Nahapiet and Ghoshal (1998), they define social capital as the sum of current and potential resources that generated by relationship network. Ostrom (2000) states that social capital refers to shared knowledge, understandings, norms, rules and expectations about patterns of interaction that groups of individuals bring to a recurrent activity. Bowles and Ginitis (2002) define social capital as the trust, a willingness to live by the norms that one's community requires, concern for one's associates. Griffith and Harvey (2004) insist that social capital is an intangible asset that is created via social relations and that can be used to facilitate action for the owner. Batt (2008) view social capital as the mobilization, use and benefit gained through accessing present and future resources through social networks. The components of social capital can be conceptualized at three different levels (Griffith and Harvey 2004). They are national level, organizational level and individual level (Kostova \& Roth 2003; Griffith \& 
Harvey, 2004). On the other hand, social capital can be divided into three dimensions: the structural dimension, the relationship dimension, and the cognitive dimension (Nahapiet \& Ghoshal, 1998). But in spite of many researches, there is no single agreed academic definition of social capital yet (Adler \& Kwon, 2002).

Facing these differences in defining the concept, identifying the roles and components of social capital become essential to understand the importance of social capital in order to upgrade woman entrepreneurs' competencies. Social capital is known to support entrepreneurs identify business opportunities. The entrepreneur can utilize their own contacts to expand their business and boost their competitive advantage (Lerner et al., 1995). The effects of social capital on a successive business can be explained by using networking theory. Luczak et al. (2010) suggest that successful business owner possesses a positive pattern of social networking behavior and these behaviors aids the owners in their acquisition of scarce resources needed to grow. According to Leana and Buren (1999), these effects are possible because there are two underlying dimensions: associability and trust (Leana \& Van Buren, 1999). Associablity implies that the individual can achieve their personal goal through the efforts and participation to meet group goals. Trust is one's confidence in another's reliability and integrity that generate long-term relationship.

Recent studies reveal that the relationships between woman entrepreneurs and social capital is especially noteworthy. Female entrepreneurs are good at expanding their social capital as a means of securing enough resource to start their business (Chung et al., 2012). A series of researches insist that women who become business owners lack many of the characteristics essential for business success and their business's characteristics are low income, low turnover and limited growth opportunities (Moore, 1999; Marlow \& Carter 2004). They also have fewer role models than men have, and the fact results in more possibility of failure in competition (Mattis, 2004). Also, International Labor Organization (ILO) reported that the problems that were being faced by woman entrepreneurs were a high rate of failure and the lack of networks that would allow them to facilitate business is one of the main reasons (Lee et al., 2011). Therefore, networking is important for female business owners as it can increase the success rate of their business (Sharafizad, 2011). That is the reason why building social networks are important to solve most woman entrepreneurs' problems. Women's reliance on smaller strong-tie networks would produce deep effects on their market performance and business surroundings (Minniti, 2010). Yunus (2007) has shown the importance of knowing other entrepreneurs and networks for female entrepreneurs' creating new business.

\section{Research Model and Hypothesis}

\subsection{Social Capital and Competitive Advantage}

Competitive advantage results from many different kinds of factors, including M\&A, diversification types, internal structure, human resource, management style and so on (Ma, 1999; King, 2007; Ismail et al., 2010). Lerner et al. (1995) insisted that relations formed by female entrepreneurs have a positive effect on their business. Thus, it is not strange to say that an entrepreneur's social capital would affect a firm's competitive advantages. For minorities who tend to be poor in conventionally perceived resources, the use of social capital becomes a more important source of advantage (Lin, 2007). SMEs and female entrepreneurs who are business minorities in Korea also can get benefits from a dense social network of the entrepreneur.

Researchers within the business discipline are also using social capital to explain precedents of firm performance (Batjargal, 2003). These researchers explain that social network can increase likelihood of business success (Smith \& Lohrke, 2008). Griffith and Harvey (2004) pay attention to a marketing manager's social capital in the market and company organization. They believe that social capital can facilitate information transfer and learning and this enables marketing managers to play a strong strategic role within a firm's network. Robben (1984) insists that entrepreneurs must expand their networks to gain a competitive advantage. It is no exaggeration to say that a small business requires myriad resources from information and capital to symbolic support (Singh et al., 1986) and those resources can be delivered from ties with entities within a social network. .

Obtaining the necessary resources has close relationships with the ability of the entrepreneur to create sustainable relationships with environments. As a result, to launch a new business and to be a successful entrepreneur, he or she must develop social exchange relationships (Hite, 2005; Smith \& Lohrke, 2008). Anderson and Jack (2002) insist that social capital facilitates coordination and cooperation of business participants by bonding the parties involved. Social capital facilitates the spread of knowledge and innovation (Batt, 2008) and social network, including insider, partner and weak links can signal a warning and influence entrepreneurial alertness (Ardichvili et al., 2003). Conversely, a lack of social capital limits economic opportunities and cause marketing to work less efficiently (Rose-Ackerman, 2001). Also, social capital is hard to 
be copied and provides entrepreneurs with unique resources that lead to competitive advantages (Luczak et al., 2010). Social relationships are complex and therefore become a source of sustainable long-term advantages.

Chung et al. (2012) insisted that opportunity is critically important to start-up and is the core of entrepreneurship. According to their study, social capital is the main source of opportunity identification and will affect the future growth potential of the entire new start up.

Based on these prior researches, this study insists that strong networks with high level of social capital play an important role in enforcing woman entrepreneurs' differentiation advantage.

Hypothesis 1. Structural social capital will positively affect the differentiation advantage of female entrepreneurs.

Hypothesis 2. Cognitive social capital will positively affect the differentiation advantage of female entrepreneurs.

Hypothesis 3. Relational social capital will positively affect the differentiation advantage of female entrepreneurs.

It is known that social capital help entrepreneurs make the better market performance. Bridging social capital can provide a start-up with a reference and also equip the organization to avoid uncertainty in the environment. Social capital is built on the relationships which require proper maintenance to be a marketing advantage, however, properly managed social capital can be used in different ways to obtain positive outcomes (Aston et al., 1999).

One of the examples is to create cost advantage. The social network can be a source of priceless information which improves a company's cost efficiency. Smith and Lohrke (2008) argue that the proper information can be helpful in eliminating unnecessary cost. Chuang et al. (2012) insisted that an organization with bonding social capital can work more smoothly and reduce its internal resource cost. Bridging social capital can provide the organization with customer information and market intelligence (Chong \& Gibbons, 1997).

In general, social ties and relationships provide persistent access to resources including free or reduced labor as well as access to better suppliers or distributors (Davidson \& Honig, 2003). Also, Social capital can reduce transaction cost of entrepreneurship by yielding a higher level of trust (Fukuyama, 1995; Batt, 2008).

Based on these prior researches, we believe that social capital could be helpful in reducing the cost of conducting everyday affairs and of doing business.

Hypothesis 4. Structural social capital will positively affect the cost advantage of female entrepreneurs.

Hypothesis 5. Cognitive social capital will positively affect the cost advantage of female entrepreneurs.

Hypothesis 6. Relational social capital will positively affect the cost advantage of female entrepreneurs.

\subsection{Competitive Advantage and Performance}

A competitive advantage is conceptualized as the implementation of a strategy not currently being implemented by other firms that facilitates the reduction of costs, and the exploitation of market opportunities (Barney, 1991). A specific resource or capability could be found to exhibit a strong correlation with competitive advantage, according to the resource heterogeneity approach. In the theory, a specific resource or capability is argued to be rare and valuable, and then the amount of that resource or capability possessed by a firm can be a source of competitive advantage (Barny, 1991; Newbert, 2008).

Social capital possessed by an entrepreneur can qualify the conditions to be a firm's resource and can affects a firm's market performance. It is logical to assume that a firm that attain a competitive advantage will be able to improve its market performance in ways that are different from its competitors whether in the form of lower cost or different value.

Ismail et al. (2010) insist that firms that enjoy cost-based competitive advantage over their rivals have been shown to exhibit better performance. Those costs-based advantages such as lower manufacturing cost, lower production cost have significant relationships with positive market performance in general (Morgan et al., 2004). In general, a firm with a competitive advantage has created more economic performance than its competitors (Peteraf \& Barney, 2003).

Founded on these prior researches, we believe that competitive advantages such as differentiation advantage and price advantage will affect market performance. 
Hypothesis 7. Differentiation advantage will positively affect the perceived market performance of female entrepreneurs.

Hypothesis 8. Cost advantage will positively affect the perceived market performance of female entrepreneurs.

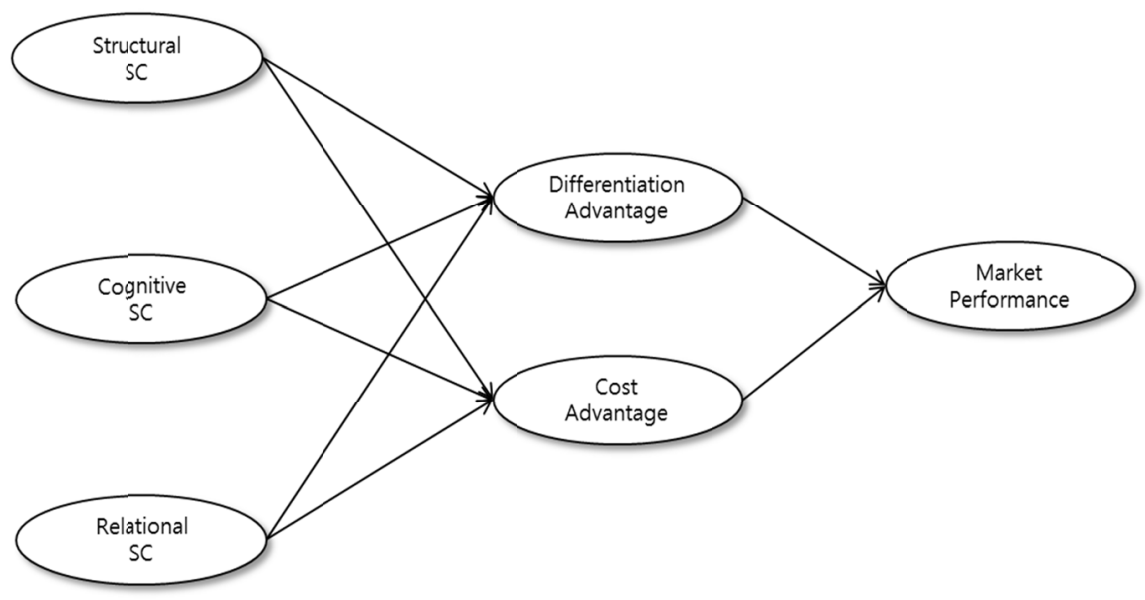

Figure 1. Research model

\section{Methodology}

\subsection{Methodology}

This study's intention is to identify the relationship between social capital and market performance mediated by competitive advantage. To achieve the proposed objectives of the research, structural equation model which is a quantitative study was selected. A quantitative analysis is proper for the case as it makes it possible to find empirical relationships between variables.

To achieve the research goal, proper measures of the constructs need to be developed before empirical test. In the first stage, all measures were borrowed from the previous literature and modified slightly to translate into Korean language for the survey. In the second stage, an initial validation process was held with the help from marketing academics and practitioners. The participants were chosen based on their prior experience and knowledge: two marketing professors who have interests in the topic and two marketing managers who are woman entrepreneurs. Through these two step process, a set of six constructs with related items emerged and the research questionnaire had been refined. These items are positively coded.

\subsection{Operationalization and Measures}

Social capital was operationalized into the three dimensions which are structural, relational and cognitive dimension (Nahapiet \& Ghoshal, 1998) and competitive advantage is defined as a degree to which a firm has reduced costs and exploited opportunities (Barney, 1991). Therefore, in the research a competitive advantage is classified into two variables and measured: competitive advantage and cost advantage. Among the many different kinds of a firm's performance, financial performance measures are used most widely in the strategy literature (Barney, 1991; Combs \& Ketchen, 1999; Newbert, 2008). However, it is highly difficult to measure a firm's objective financial performance because a private small firms characteristics that don't want to reveal their financial status to outsiders. Thus market performance was measured by adopting Morgan et al. (2004)'s widely used market performance scale. All these items are positively coded.

Table 1. List of measurement

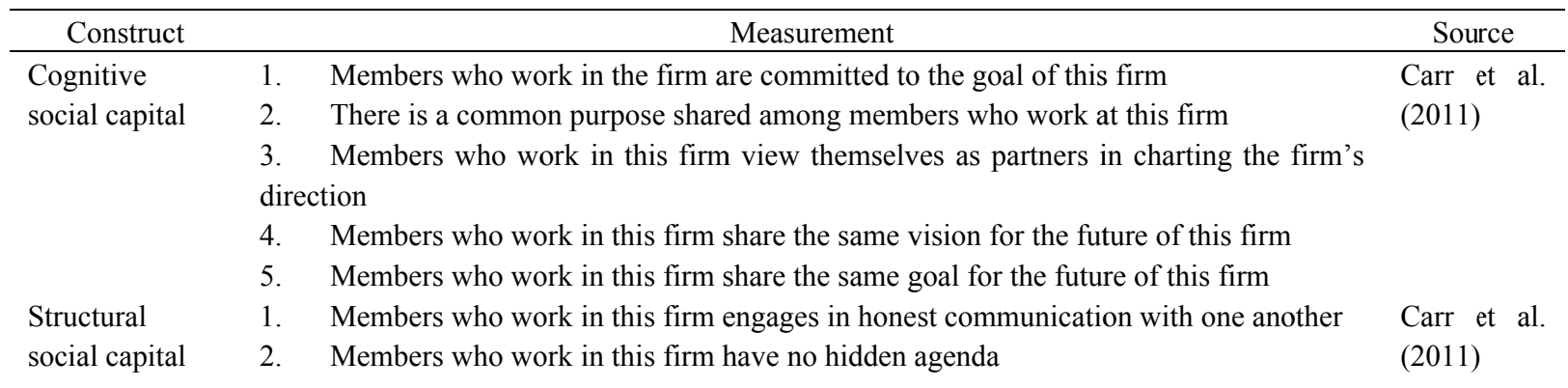




\begin{tabular}{|c|c|c|}
\hline Construct & Measurement & Source \\
\hline & $\begin{array}{l}\text { 3. Members who work in this firm willingly share information with one another } \\
\text { 4. Members who work in this firm takes advantage of their relationships to share } \\
\text { information }\end{array}$ & \\
\hline $\begin{array}{l}\text { Relational } \\
\text { social capital }\end{array}$ & $\begin{array}{l}\text { 1. Members who work in this firm have confidence in one another } \\
\text { 2. Members who work in this firm show a great deal of integrity with each other } \\
\text { 3. Members who work in this firm trust each other } \\
\text { 4. Members who work in this firm are usually considerate of each other's feeling } \\
\text { 5. Members who work at this firm believe in each other }\end{array}$ & $\begin{array}{l}\text { Carr et al. } \\
(2011)\end{array}$ \\
\hline $\begin{array}{l}\text { Market } \\
\text { differentiation } \\
\text { advantage }\end{array}$ & $\begin{array}{l}\text { "Please rate your business relative to your major competitors in terms of marketing } \\
\text { capabilities." } \\
\text { 1. Development of customer-driven product } \\
\text { 2. Quality of product and service } \\
\text { 3. Ability to provide differentiated value } \\
\text { 4. Customer service and support }\end{array}$ & $\begin{array}{l}\text { Morgan et } \\
\text { al. (2004), } \\
\text { Vorhies and } \\
\text { Morgan } \\
(2005)\end{array}$ \\
\hline Cost advantage & $\begin{array}{l}\text { "Please rate your business relative to your major competitors in terms of marketing } \\
\text { capabilities." } \\
\text { 1. Lower cost than competitor's cost } \\
\text { 2. Effective management for cost control } \\
\text { 3. Lower price to customers.. . }\end{array}$ & $\begin{array}{l}\text { Morgan et } \\
\text { al. (2004), } \\
\text { Vorhies and } \\
\text { Morgan } \\
(2005)\end{array}$ \\
\hline $\begin{array}{l}\text { Market } \\
\text { performance }\end{array}$ & $\begin{array}{l}\text { "Please evaluate the market performance of your business over the past year (the next } \\
\text { twelve months) relative to your major competitor" } \\
\text { 1. Growth in sales revenue } \\
\text { 2. Increasing sales } \\
\text { 3. Reaching a financial goal }\end{array}$ & $\begin{array}{l}\text { Vorhies and } \\
\text { Morgan } \\
(2005) \text {, } \\
\text { Zhou et al. } \\
(2009)\end{array}$ \\
\hline
\end{tabular}

\subsection{Research Sampling}

The data as collected from face-to-face direct personal interviews with woman entrepreneurs in Korea from April to May 2014. Finally, a data set was generated based on the interview survey. 257 samples were collected from major cities including Seoul, which were confined only to business owners who has less than ten employees. According to the related Korean laws, small business can be defined by the number of employees and ten is the maximum number.

Table 2. Sample characteristics

\begin{tabular}{ccc}
\hline Category & Explanation & Frequency $(\%)$ \\
\hline & Under 29 & $34(13 . \%)$ \\
Age group & $30-39$ & $67(26.1 \%)$ \\
& $40-49$ & $98(38.1 \%)$ \\
& $50-59$ & $48(18.7 \%)$ \\
Education Experience & Above 60 & $10(3.9 \%)$ \\
& High school & $108(42.0 \%)$ \\
& Commity college & $52(20.2 \%)$ \\
Business Domain & University & $81(31.5 \%)$ \\
& Graduate school & $16(6.2 \%)$ \\
& Manufacturing & $7(2.7 \%)$ \\
& Construction & $3(1.2 \%)$ \\
& Retailing $\&$ wholesaling & $88(34.2 \%)$ \\
& Restaurant & $90(35 . \%)$ \\
Size by employees & Service & $60(23 . \%)$ \\
& Others & $9(3.5 \%)$ \\
& $1-2$ & $111(43 . \%)$ \\
& $3-4$ & $103(40.1 \%)$
\end{tabular}




\section{Research Results}

\subsection{Reliability and Validity}

Reliability and validity of measures were tested in two continuous stages: General Reliability Analysis and Factor Analysis. Internal consistency was assessed by calculating Cronbach's alpha score. Cronbach's alpha scores are found to be greater than 0.8 and the reliability are accepted in accordance with Nunnally (1967)'s rule.

Table 3. Cronbach's alpha

\begin{tabular}{ccccc}
\hline & Construct & Mean (Std. Dev.) & Cronbach's alpha & Number of items \\
\hline Exogenous & Cognitive social capital & $3.70(.90)$ & .923 & 5 \\
variables & Structural social capital & $2.80(1.11)$ & .922 & 4 \\
& Relational social capital & $3.73(.81)$ & .808 & 5 \\
Endogenous & Differentiation Advantage & $3.41(.83)$ & .828 & 3 \\
variables & Cost Advantage & $3.26(.81)$ & .866 & 2 \\
& Market performance & $3.07(1.06)$ & .927 & 3 \\
\hline
\end{tabular}

As a next step factor analysis was performed to test the validity of variables. For the analysis, we adopted PCA (principal component analysis) extraction method with a VARIMAX rotation option. Three factors in exogenous variables and three factors from endogenous variables are extracted successfully.

Table 4. Factor analysis of exogenous variables

\begin{tabular}{cccccc}
\hline Construct & Igen value & Item & Factor 1 & Factor 2 & Factor 3 \\
\hline Cognitive, social & 5.606 & $\mathrm{sc} 10$ & $\mathbf{. 8 8 1}$ & .042 & .163 \\
capital & & $\mathrm{sc13}$ & $\mathbf{. 8 5 8}$ & .074 & .148 \\
& & $\mathrm{sc} 12$ & $\mathbf{. 8 5 6}$ & .087 & .192 \\
& & $\mathrm{sc} 11$ & $\mathbf{. 8 5 6}$ & .086 & .246 \\
Structural social & 2.768 & $\mathrm{sc} 14$ & $\mathbf{. 7 8 0}$ & .117 & .267 \\
capital & & $\mathrm{sc03}$ & .109 &. $\mathbf{9 1 6}$ & .099 \\
& & $\mathrm{sc04}$ & .080 & $\mathbf{. 9 1 2}$ & .073 \\
Relational social & \multirow{2}{*}{1.636} & $\mathrm{sc02}$ & .037 & $\mathbf{. 8 9 1}$ & .121 \\
capital & & $\mathrm{sc01}$ & .105 &. $\mathbf{8 2 2}$ & .202 \\
& & $\mathrm{sc06}$ & .147 & -.021 & $\mathbf{. 8 2 2}$ \\
& & $\mathrm{sc05}$ & .132 & .008 & $\mathbf{. 8 0 6}$ \\
& & $\mathrm{sc09}$ & .196 & .260 & $\mathbf{. 6 7 7}$ \\
& & $\mathrm{sc07}$ & .281 & .242 & $\mathbf{. 6 3 9}$ \\
& & $\mathrm{sc08}$ & .215 & .161 & $\mathbf{. 6 1 8}$ \\
& & & $40.041 \%$ & $19.768 \%$ & $11.688 \%$ \\
\hline
\end{tabular}

Table 5. Factor analysis of endogenous variables

\begin{tabular}{cccccc}
\hline Construct & Igen value & Item & Factor 1 & Factor 2 & Factor 3 \\
\hline Market & 2.613 & $\mathrm{mp02}$ & $\mathbf{. 9 1 3}$ & .218 & .164 \\
performance & & $\mathrm{mp03}$ & $\mathbf{. 8 8 5}$ & .183 & .165 \\
& & $\mathrm{mp01}$ & $\mathbf{. 8 7 7}$ & .294 & .115 \\
Differentiation & 2.227 & $\mathrm{ad04}$ & .150 & $\mathbf{. 8 4 2}$ & .175 \\
advantage & & $\mathrm{ad03}$ & .206 & $\mathbf{. 8 4 1}$ & .191 \\
& & $\mathrm{ad05}$ & .328 & $\mathbf{. 7 6 2}$ & .136 \\
Cost advantage & \multirow{2}{*}{1.518} & $\mathrm{ad02}$ & .087 & .175 & $\mathbf{. 8 5 5}$ \\
& & $\mathrm{ad01}$ & .218 & .182 & $\mathbf{. 7 9 6}$ \\
& & & $32.664 \%$ & $27.835 \%$ & $18.974 \%$ \\
& & & & $79.474 \%$ & \\
\hline
\end{tabular}

\subsection{Test Results}

This study adopts SEM (structural equation modeling) technique to prove the theory. The fit test resulted in chi-square statistics of $512.777(\mathrm{p}=.000$, d.f $=219)$ and chi-square value was satisfactory in general. Other fit 
statistics such as GFI, CFI, NFI, SRMR could be more proper for assessing the model fit than single chi-square value (Bagozzi and Yi 1988). In the testing all these fits also indicates satisfactory outcomes. Therefore, further analysis of a causal relationship between the variables was conducted as a final stage.

According to the results, hypothesis $\mathrm{H} 1, \mathrm{H} 2, \mathrm{H} 4, \mathrm{H} 5, \mathrm{H} 7$, and $\mathrm{H} 8$ are significant while $\mathrm{H} 3$ and $\mathrm{H} 6$ are not significant. Both structural social capital and cognitive social capital are positively and directly linked to differentiation advantage and cost advantage. Also, these advantages affect market performance positively. However, the effects of relational social capital are not supported. Its relationship with any kind of advantage are not statistically supported.

Table 6. SEM analysis results

\begin{tabular}{|c|c|c|c|c|}
\hline Hypothesis & Estimate (Std. estimate) & S.E & C.R & $p^{*}(p<.05)$ \\
\hline H1. Structural SC $\rightarrow$ Differentiation advantage & $\begin{array}{c}.315 \\
(.317)\end{array}$ & .066 & 4.750 & $.000^{*}$ \\
\hline H2. Cognitive $\mathrm{SC} \rightarrow$ Differentiation advantage & $\begin{array}{c}.502 \\
(.565)\end{array}$ & .072 & 6.968 & $.000^{*}$ \\
\hline H3. Relational SC $\rightarrow$ Differentiation advantage & $\begin{array}{c}-.186 \\
(-.163)\end{array}$ & .095 & -1.954 & $.051^{*}$ \\
\hline H4. Structural SC $\rightarrow$ Cost advantage & $\begin{array}{c}.473 \\
(.451)\end{array}$ & .082 & 5.798 & $.000^{*}$ \\
\hline H5. Cognitive SC $\rightarrow$ Cost advantage & $\begin{array}{c}.205 \\
(.219)\end{array}$ & .081 & 2.540 & $.011^{*}$ \\
\hline H6. Relational SC $\rightarrow$ Cost advantage & $\begin{array}{c}-.019 \\
(-.016)\end{array}$ & .114 & -.166 & .868 \\
\hline H7. Differentiation advantage $\rightarrow$ Market performance & $\begin{array}{c}.603 \\
(.507)\end{array}$ & .081 & 7.417 & $.000^{*}$ \\
\hline H8. Cost advantage $\rightarrow$ Market performance & $\begin{array}{c}.297 \\
(.263)\end{array}$ & .085 & 3.504 & $.000^{*}$ \\
\hline
\end{tabular}

* Model fit $=$ Chi-square $=512.777$ (d.f=219, $\mathrm{p}=.000), \mathrm{GFI}=.855, \mathrm{CFI}=.923, \mathrm{NFI}=.874, \mathrm{SRMR}=.068$, RMSEA $=.072$

\section{Conclusions}

\subsection{Finding and Implication}

This research has surveyed some of the principal facts about woman entrepreneurship and presents empirical findings about the relationship between major variable. There are yet many hurdles to be a successful entrepreneur, particularly in case of a woman. This work suggests a possibility that a woman's social capital could be an answer to gain business advantages. This study proposes several empirical findings that have the potential for further research.

First, this study addresses the importance of woman entrepreneurs in the small business. Due to their increasing economic power, more women start their own business and become new business actors. The demand for research to explain this new movement is emphasized once more.

Second, the use of social capital components and their relationships with marketing advantages are offered. Social capital consists of three variables which are structural, cognitive and relational social capital. This study finds out that both differentiation and cost advantage are affected by cognitive and structural social capital. This outcome is coherent with the previous researches on women entrepreneur. According to the Kauffman Foundation Research (Padma, 2013), woman entrepreneurs are concerned about IP (intellectual property), seek mentoring and experienced, well developed professional networks. Most woman entrepreneurs know that social capital building through networking is an effectual means to compete. However, relational social capital's effects on those advantages are not.

Third, differentiation and cost advantage affect market performance positively as the study expected. It gives implication that those business advantages are too essential to be neglected by any gender of entrepreneurs. Woman entrepreneurs also make an attempt to establish substantial business advantages just like man counterparts. 


\subsection{Limitation}

Regardless the findings of this study, there are several research limitations. Confirmation of these speculations must await further research.

First, this research focused on social capital of woman entrepreneurs and its effects on market performance mediated by business advantages. However, there are more variables that can give impact to the relationships. Further research could consider more extensive variable to explain women entrepreneur.

Second, the generalization of the research findings will be limited to Asian nations because the sample was mainly made from female Korean business owners. Confucianism is very popular among the Asian countries such as China, Japan, Vietnam and Korea and there has been a similar negative viewpoint about the business activities of adult females. Thus, this research results can be portioned out among Asian countries. However, it is not clear if the findings can be applied to western nations with different cultural backgrounds. The comparison between Asian and Western countries will provide readers with more practical implications.

Third, this study doesn't consider country differences in women entrepreneur's motivations. Granting to the GEM 2008 (Global Entrepreneur Monitor, 2008) report, there are difference in motivation even among Asian nations. For instance Malaysian and China are efficiency driven, while Australia, Japan and Korea are innovation driven. There is a possibility that women have different motivations based on the economic situation of their nation. Women in poor countries start a business out of necessity because of the lack of employment in the job market, and women in rich countries start business even when other job opportunities exist to get a better paid job. As a result this research needs to be expanded to more general settings across countries.

\section{References}

Adler, P., \& Kwon, S. (2002). Social Capital: Prospects for a New Concept. Academy of Management Review, 27(1), 17-40. http://dx.doi.org/10.5465/AMR.2002.5922314.

Aldrich, H. (1989). Networking among Woman entrepreneurs. In O. Hagan, C. Rivchun, \& D. Sexton (Eds.), Women-owned Businesses (pp. 103-132). New York, Praeger.

Anderson, A., \& Jack, S. (2002). The Articulation of Social Capital in Entrepreneurial Networks. Entrepreneurship \& Regional Development: An International Journal, 14, 193-210. http://dx.doi.org/10.1080/08985620110112079.

Ardichvili, Cardozo, A. R., \& Ray, S. (2003). A Theory of Entrepreneurial Opportunity Recognition and Development. Journal of Business Venturing.

Aston, N., Nathanson, C., Shoen R., \& Kim, Y. (1999). Family Demography, Social Theory, and Investment in Social Capital. Population and Development Review, 25(1), 1-31. http://dx.doi.org/10.1111/j.17284457.1999.00001.x.

Bagozzi, R., \& Youjae, Y. (1988). On the Evaluation of Structural Equation Models. Journal of the Academy of Marketing Science, 16(1), 74-94. http://dx.doi.org/10.1007/BF02723327.

Barney, J. B. (1991). Firm Resources and Sustained Competitive Advantage. Journal of Management, 17(1), 99-120. http://dx.doi.org/10.1177/014920639101700108.

Batjargal, B. (2003). Social Capital and Entrepreneurial Performance in Russia: A Longitudinal Study. Organization Studies, 24(4), 535-566. http://dx.doi.org/10.1177/0170840603024004002.

Batt, P. J. (2008). Building Social Capital in Networks. Industrial Marketing Management, 37, 487-491. http://dx.doi.org/10.1016/j. on-demand. 2008.04.002

Berg, N. (1997). Gender, Place and Entrepreneurship. Entrepreneurship \& Regional Development: An International Journal, 9(4), 259-268. http://dx.doi.org/10.1080/08985629700000015.

Birley, S. (1989). Female Entrepreneurs: Are They Really Different?. Journal of Small Business Management, 27(1), 7-31.

Blau, F. D., \& Kahn, L. M. (2007). Changes in the Labor Supply Behavior of Married Women: 1980-2000. Journal of Labor Economics, 25(3), 393. http://dx.doi.org/10.3386/w11230

Bowles, S., \& Gintis, H. (2002). Social Capital and Community Governance. Economic Journal, 112(483), 419-436. http://dx.doi.org/10.1111/1468-0297.00077

Budig, M. K. (2006). Intersections on the Road to Self-Employment: Gender, Family and Occupational Class. Social Forces, 84(4), 2223-2239. http://dx.doi.org/10.1353/sof.2006.0082 
Buttner, E. H. (1993). Female Entrepreneurs: How Far Have They Come?. Business Horizons, March-April, 59-65.

Carr, J. C., Cole, M. S., Ring, J. K., \& Blettner, D. P. (2011). A Measure of Variations in Internal Social Capital among Family Firms. Entrepreneurship Theory and Practice, November, 1207-1227. http://dx.doi.org/10.1111/j.1540-6520.2011.00499.x

Chaganti, R., \& Parasuraman, S. (1996). A Study of the Impact of Gender on Business Performance and Management Patterns in Small Business. Entrepreneurship Theory and Practice, 21(2), 73-85.

Chong, L., \& Gibbons, P. (1997). Corporate Entrepreneurship: The Roles of Ideology and Social Capital. Group and Organization Management, 22, 10-30. http://dx.doi.org/10.1016/S0883-9026(01)00068-4.

Chuang, L.-M., Kiu, C.-C., Huang, C.-M., \& Tang, H.-C. (2012). An Evaluation Model of Female Entrepreneurship in the Service Industry-Human Capital, Social Capital and Opportunity Recognition Perspective. International Research Journal of Finance and Economics, 85, 56-67.

Coleman, S. (2007). The Role of Human and Financial Capital in the Profitability and Growth of Women-owned Small Firms. Journal of Small Business Management, 45(3), 303-319. http://dx.doi.org/10.1111/j.1540627X.2007.00214.x.

Combs, J. G., \& Ketchen, D. J. (1999). Explaining Interfirm Cooperation and Performance: Toward a Reconciliation of Predictions from the Resource-based View and Organizational Economics. Strategic Management Journal, 20(9), 867-888.

Davidson, P., \& Honig, B. (2003). The Role of Social and Human Capital among Nascent Entrepreneurs. Journal of Business Venturing, 18, 301-331. http://dx.doi.org/10.1016/S0883-9026(02)00097-6

Devine, T. (1994). Changes in Wage-and-salary Returns to Skill and the Recent Rise in Female Self-employment. American Economic Review, 84(2), 108-113.

Dhaliwal, S., Scott, J., \& Hussain, J. (2009). Help or Hindrance? South Asian Women in the Family Firm. Queen's University Management School Working Paper Series, MS_WPS_MAN_09_8.

Fielden, S., Davidson, M., Dawe, A., \& Makin, P. (2003). Factors Inhibiting the Economic Growth of Female Owned Small Businesses in North England. Journal of Small Business and Enterprise Development, 10(3), 30-37. http://dx.doi.org/10.1108/14626000310473184

Fukuyama, F. (1995). Social Capital and the Global Economy. Foreign Affairs, 74(5), 89-103.

Goldin, C. (1990). Understanding the Gender Gap: An Economic History of American Women. New York: Oxford University Press.

Griffith, D. A., \& Harvey, M. G. (2004). The Influence of Individual and Firm Level Social Capital of Marketing Managers in a Firm's Global Network. Journal of World Business, 39, $244-254$. http://dx.doi.org/10.1016/j.jwb.2004.04.004

Hisrich, R. D., Brush, C. G., Good, D., \& De Souza, G. (1996). Some Preliminary Findings on Performance in Entrepreneurial Ventures: Does Gender Matter?. Frontiers of Entrepreneurship Research, Babson College, Wellesley.

Hite, J. (2005). Evolutionary Processes and Paths of Relationally Embedded Network Ties in Emerging Entrepreneurial Firms. Entrepreneurship Theory \& Practice, 29, 113-144. http://dx.doi.org/10.1111/j.15406520.2005.00072.x

Ismail, A. I., Rose, R. C., Abdullah, H., \& Uli, J. (2010). The Relationship between Organisational Competitive Advantage and Performance Moderated by the Age and Size of Firms. Asian Academy of Management Journal, 15(2), 157-173.

King, A. W. (2007). Disentangling Interfirm and Intrafirm Causal Ambiguity: A Conceptual Model of Causal Ambiguity and Sustainable Competitive Advantage. Academy of Management Review, 32(1), 156-178. http://dx.doi.org/10.5465/AMR.2007.23464002

Kostova, T., \& Roth, K. (2003). Social Capital in Multinational Corporations and a Micro-macro Model of Its Formulation. Academy of Management Review, 28(2), 297-313. http://dx.doi.org/10.5465/AMR.2003. 9416356

Leana, C. R., \& Van Buren, H. J. (1999). Organizational Social Capital and Employment Practices. Academy of Management Review, 24(3), 538-555. http://dx.doi.org/10.5465/AMR.1999.2202136 
Lee, J. H., Sohn, S. Y., \& Ju, Y. H. (2011). How Effective Is Government Support for Korean Woman entrepreneurs in Small and Medium Enterprise?. Journal of Small Business Management, 49(4), 599-616.

Lee, M. A., \& Rendall, M. S. (2001). Self-employment Disadvantage in the Working Lives of Blacks and Females. Population Research and Policy Review, 20, 291-320. http://dx.doi.org/10.1023/A:10118870 13195

Lerner, M., Brush, C. G., \& Hisrich, R. D. (1995). Factors Affecting Performance of Israeli Woman entrepreneurs: An Examination of Alternative Perspectives. In W. D. Bygrave, B. J. Bird, S. Birley, C. Churchill, M. Hay, R. H. Keeley, \& W. E. Wetzel, Jr. (Eds.), Frontiers of Entrepreneurial Research (pp. 308-322). Boston, MA: Babson College.

Lin, X. (2007). Chinese Entrepreneurs in Network Marketing Organizations: A Culture-Moderated Social Capital Perspective. Journal of Small Business and Entrepreneurship, 20(3), 273-288. http://dx.doi.org/10.1080/08276331.2007.10593400

Low, A. (2008). Economic Outcomes of Female Immigrant Entrepreneurship. International Journal of Entrepreneurship and Small Business, 5(3/4), 224-240. http://dx.doi.org/10.1504/IJESB.2008.017301

Luczak, C., Mohan-Neill, S., \& Hills, G. (2010). National Culture, Market Orientation, and Network-derived Benefits: Conceptual Model for Service SME's. Academy of Entrepreneurship Journal, 16(2), 1-20.

Ma, H. (1999). Anatomy of Competitive Advantage: A SELECT Fraework. Management Decision, 37(9), 709-718.

Mackie, V. (2003). Feminism in Modern Japan: Citizenship, Embodiment and Sexuality. Cambridge, UK: Cambridge University Press. http://dx.doi.org/10.1080/1037139032000156379.

Marlow, S., \& Carter, S. (2004). Accounting for Change: Professional Status, Gender Disadvantage and Self Employment. Women in Management Review, 19(3), 154-163. http://dx.doi.org/10.1108/096494204 10518395

Mattis, M. (2004). Woman Entrepreneurs: Out from under the Glass Ceiling. Women in Management Review, 19(3), 154-163. http://dx.doi.org/10.1108/09649420410529861

McKay, R. (2001). Woman entrepreneurs: Moving Beyond Family and Flexibility. International Journal of Entrepreneurial Behaviour and Research, 7(4), 148-165. http://dx.doi.org/10.1108/EUM0000000005764

Minniti, M. (2010). Female Entrepreneurship and Economic Activity. European Journal of Development Research, 22(3), 294-312. http://dx.doi.org/10.1057/ejdr. 2010.18

Minniti, M., \& Levesque, M. (2008). Recent Development in the Economics of Entrepreneurship. Journal of Business Venturing, 23(6), 603-612. http://dx.doi.org/10.1016/j. jbusvent. 2008.01.001

Minniti, M., \& Naude, W. (2010). What Do We Know about the Pattern and Determinants of Female Entrepreneurship across Countries?. European Journal of Development Research, 22(3), 277-293.

Moore, D. P. (1999). Woman Entrepreneurs: Approaching New Millennium. In G. N. Powel (Eds.), Handbook of Gender and Work. Thousand Oaks, CA: Sage.

Morgan, N. A., Kaleka, A., \& Katsikeas, C. S. (2004). Antecedents of Export Venture Performance: A Theoretical Model and Empirical Assessment. Journal of Marketing, 68, 90-108. http://dx.doi.org/10.1509/ jmkg.68.1.90.24028

Nahapiet, J., \& Ghoshal, S. (1998). Social Capital, Intellectual Capital, and the Organizational Advantage. Academy of Management Review, 23(2), 242-266. http://dx.doi.org/10.5465/AMR.1998.533225

Newbert, S. C. (2008). Value, Rareness, Competitive Advantage, and Performance: A Conceptual-level Empirical Investigation of the Resource-based View of the Firm. Strategic Management Journal, 29, 745-768. http://dx.doi.org/10.1002/smj.686

Padma, S. (2013). An Analysis of Woman Entrepreneurs in Asia-Pacific Countries. Advances in Management, $6(6), 23-27$.

Parker, S. (2009). The Economics of Entrepreneurship. Cambridge: Cambridge University Press.

Peng, M. W., \& Luo Y. (2000). Managerial Ties and Organization Performance in a Transition Economy: The Nature of a Micro-macro Link. Academy of Management Journal, 43(3), 486-501. http://dx.doi.org/10. $2307 / 1556406$. 
Peteraf, M. A., \& Barney, J. B. (2003). Unraveling the Resource-based Tangle. Managerial and Decision Economics, 24, 309-323. http://dx.doi.org/10.1002/mde.1126

Putnam, R. D. (2000). Bowling Alone: The Collapse and Revival of American Community. New York: Simon and Schuster. Review, 26, 431-445.

Robben, A. (1984). Entrepreneurs and Scale: Interactional and Institutional Constraints on the Growth of Small Scale Enterprises in Brazil.

Rose-Ackerman, S. (2001). Trust and Honesty in Post-socialist Societies. Kyklos, 54(2/3), 415-444. http://dx.doi.org/10.1111/1467-6435.00161

Sandra, K.-K., Ngoc, S. D., \& Chatherine, A. C. (2006). Impact of Human Resource Management: SME Performance in Vietnam. Journal of Developmental Entrepreneurship, 11(1), 79-95. http://dx.doi.org/10. 1142/S1084946706000271.

Sharafizad, J. (2011). Determinants of Business Networking Behaviour of Women in Small Business. Small Enterprise Research, 18, 158-160. http://dx.doi.org/10.5172/ser.2011.18.2.158

Shim, S., \& Eastlick, M. A. (1998). Characteristics of Hispanic Female Business Owners: An Exploratory Study. Journal of Small Business Management, 36(3), 18-34.

Singh, J., Tucker, D., \& House, R. (1986). Organizational Legitimacy and the Liability of Newness. Administration Science Quarterly, 31, 171-193.

Smith, D. A., \& Lohrke, F. T. (2008). Entrepreneurial Network Development: Trusting in the Process. Journal of Business Research, 61, 315-322. http://dx.doi.org/10.1016/j.jbusres.2007.06.018

Snyder, M. G. (1995). Feminist Theory and Planning Theory: Lessons from Feminist Epistemologies. Berkely Planning Journal, 10, 91-106.

Stanger, A., Roffey, B., Forsaith, D., McInnes, E., Petrone, F., Symes, C., \& Xydias, M. (2002). Gender Differences in Small Business Owner Managers. The International Journal of Entrepreneurship and Innovation, 3(2), 93-107.

Steward, W. H. Jr., Garland, J. C., Carland, J. W., Watson, W., \& Sweo, R. (2003). Entrepreneurial Disposition and Goal Orientations: A Comparative Exploration of United States and Russian Entrepreneurs. Journal of Small Business Management, 41(1), 27-46. http://dx.doi.org/10.1111/1540-627X.00065

Verheul, I. (2003). Commitment or Control? Human Resource Management in Female and Male-led Businesses. Strategic Study B200206, Zoetermeer: EIM Business and Policy Research.

Vorhies, D. W., \& Morgan, A. (2005). Benchmarking Marketing Capability for Sustainable Competitive Advantage. Journal of Marketing, 69, 80-94. http://dx.doi.org/10.1509/jmkg.69.1.80.55505

Williams, D. R. (2004). Effects of Childcare Activities on the Duration of Self-employment in Europe. Entrepreneurship Theory and Practice, 28(5), 467-485.

Young, R. (2008). Comparative Study of Work-life Balance in Franchised and Independently Owned Small Business Models. Griffith University, Meadowbrook, QLD.

Yunus, M. (2007). The Nobel Peace Prize 2006 Nobel Lecture. Law and Business Review of the Americas, 13(2), 267-275.

Zhou, K. Z., Brown, J. R., \& Dev, C. S. (2009). Market Orientation, Competitive Advantage, and Performance: A Demand-based Perspective. Journal of International Marketing, 11(4), 32-55. http://dx.doi.org/10.1016/j. jbusres.2008.10.001

\section{Copyrights}

Copyright for this article is retained by the author(s), with first publication rights granted to the journal.

This is an open-access article distributed under the terms and conditions of the Creative Commons Attribution license (http://creativecommons.org/licenses/by/3.0/). 